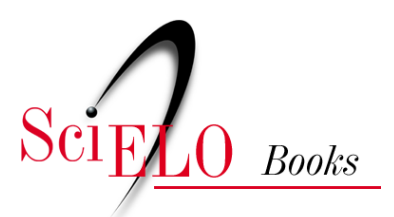

\title{
2. De cuando Katherine vio a Dalí
}

\author{
César Augusto Tapias Hernández
}

\section{SciELO Books / SciELO Livros / SciELO Libros}

TAPIAS HERNÁNDEZ, C.A. De cuando Katherine vio a Dalí. In: Historias de familia: Etnografía delirante sobre el amor, la violencia y las drogas [online]. Bogotá: Editorial Universidad del Rosario, 2014, pp. 9-11. Textos de ciencias humanas collection. ISBN: 978-958-738-543-4. https://doi.org/10.7476/9789587385434.0003.

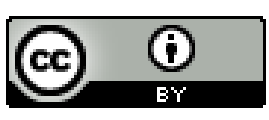

All the contents of this work, except where otherwise noted, is licensed under a Creative Commons Attribution 4.0 International license.

Todo o conteúdo deste trabalho, exceto quando houver ressalva, é publicado sob a licença Creative Commons Atribição 4.0.

Todo el contenido de esta obra, excepto donde se indique lo contrario, está bajo licencia de la licencia Creative Commons Reconocimento 4.0 . 


\title{
2. De cuando Katherine vio a Dalí
}

\author{
¡Guácala!, gritó un niño con cara de asco. \\ Maestra Topolobampacracia, ¿hay ciudades que tengan árboles \\ y gallinas? La verdad, no lo creo. \\ Francisco Hinojosa, Ana, ¿verdad?
}

"El manifiesto místico", para Dalí — recuerde, Kate, que se llama Salvador Dalí-, comenzaba una nueva era. Triunfa la mística y, con ella, la mística nuclear, cuya explosión se confunde con la explosión hacia un nuevo clasicismo. Como de costumbre, las noticias de arte propusieron maliciosamente la siguiente pregunta retórica: ¿no es imposible que en el sucesivo Dalí consagre más atención a lo consciente que a lo inconsciente? Si realmente fuera así, no le faltaría más que convertirse en el pintor académico más grande del siglo Xx...

Y Katherine, como nunca, supremamente atenta escuchaba y seguía por sí misma las palabras leídas y se dejaba llevar por los dibujos esos de un señor de largos bigotes llamado Dalí, quien en cualquier rostro pintaba el rostro de la mujer que amaba... Estamos en la biblioteca de la Universidad de Antioquia, pero cuando entramos le dije que aquí podría ella encontrar algo más que libros: "En este lugar es donde están todos los secretos del mundo, lo que querrás saber lo hallarás en un libro...."

Y Kate no dijo nada... Solo tomaba uno y otro libro y otro y les buscaba el derecho y les leía el título... desechando los que poco le interesaban, pendiente quizás de las formas, el tamaño de las letras o el olor entre sus páginas... Quizás la textura del papel...

- ¿Todos los secretos?

Me preguntó incrédula, y yo asentí. Había respeto y admiración por cada libro; eso se notaba en la forma como los miraba, los abría y los ponía de nuevo en 
su puesto para sacar otros... Y otros. ¿No querrás ver pinturas, Kate? Y dijo que más luego. Entonces le explique del porqué los libros tenían unos números y unas letras y quién los organizaba.

-Vamos, pues, por las pinturas — dijo.

De camino al otro lado de la biblioteca, no dejaba de admirarse por la cantidad de libros y por los computadores donde la gente buscaba... Antes que a Dalí, prefirió ver un manual de pintura al óleo, y cuando le pareció conveniente dijo: "muéstreme, pues.... Yo le mostraba algunas, alternándolas con historias sobre lo que Dalí quería pintar, aquello que en ocasiones a Kate no le parecía correcto, como los desnudos:

- Porque uno no debe estar desnudo en la calle — decía.

- Pero es solo una pintura, incluso la calle está pintada...

Muy rápido se pilló que cada pintura tenía un numerito en una esquina y entonces buscaba al final de cada página el número que correspondía a la pintura tal, y leía el título... Y sobre la que ella se detenía, yo le preguntaba: "Kate, decime ¿qué hay ahí?, ¿qué ves ahí?”. Y ella, con palabras y frases sueltas, decía algo más que cosas sueltas...

—Un árbol. Una copa. Señores peleando. Una Virgen... Una araña. Unos muebles volando... Humm. Mira, César, a esa gente se les voló la casa. Una niña cobijando a un perro.

- ¿Con qué?

-Con un tapete, ¿no ves?

- ¿Un tapete?

- Sí, un tapete de agua... Una mariposa con una boca como de otra mariposa... Se le está dañando el cuerpo a la gente.

-Y ¿cómo se llamará esa?

— ¿La 963? Per-so-na-je de ro-di-llas. Bo-ce-to (Boceto).

- ¿Ya viste ese reloj?

— Sí, se está dañando, como que se está derritiendo... y por los pulmones.

— ¿Por los pulmones? Y ¿dónde quedan los pulmones de un reloj?

-... En los números...

— ¿En los números? Ve, yo sí decía... y cómo se llamará ese.

— ¿El 964? El re-loj blan-do (El reloj blando)...

-Kate, decime, ¿qué es algo blando?

- Un pan, o un roscón... Algo así para que uno no se le caigan los dientes...

Y al final Kate supo cómo sonaban la $d$ con $r$ y la $a$ : Dra. Y sí Dalí fue lo más grande del siglo Xx. Alegrémonos porque cada niño o niña, puede revertirlo y 
hacerse él o ella lo más grande del mundo. Con esa forma de mirar el mundo, el mundo se queda pequeño, y Dalí termina siendo un curandero de relojes que se derriten por los pulmones... 